\title{
Increased Killer Cell Activity in Insulin Dependent (Type 1) Diabetes Mellitus
}

\author{
M. Sensi ${ }^{1}$, P. Pozzilli ${ }^{1,3}$, A. N. Gorsuch ${ }^{1}$, G. F. Bottazzo ${ }^{2}$, and A. G. Cudworth ${ }^{1}$ \\ ${ }^{1}$ Department of Diabetes, St. Bartholomew's Hospital, ${ }^{2}$ Department of Immunology, Middlesex Hospital, London, England, \\ and ${ }^{3}$ Cattedra di Endocrinologia, University of Rome, Rome, Italy
}

Summary. Antibody dependent cell mediated cytotoxicity in relation to the levels of circulating killer cells was investigated in 16 newly diagnosed classical insulin dependent (Type 1) diabetics, 11 islet cell antibody positive non diabetic children with at least one HLA haplotype in common with their diabetic sibling, and in 15 normal controls. Antibody dependent cell mediated cytotoxicity was evaluated using, as target, ${ }^{51} \mathrm{Cr}$ labelled human $0^{+}$erythrocytes sensitised with an anti-CD antiserum. Killer cells were measured by the low affinity E-rosetting cell technique. Increased killer cell levels ( $>$ normal mean $+2 \mathrm{SD})$ were accompanied by a significant enhancement in antibody dependent cell mediated cytotoxicity both in newly diagnosed diabetics $(p<0.05)$ and in unaffected siblings $(p<0.01)$. These preliminary results indicate that raised antibody dependent cell mediated cytotoxicity is a feature of insulin dependent diabetes at diagnosis and suggest that active B cell damage might be occurring some time before the onset of clinical symptoms.

Key words: Newly diagnosed insulin dependent (Type 1) diabetics, antibody dependent cell mediated cytotoxicity, killer or $\mathrm{K}$ cells, islet cell antibodies, genetically susceptible unaffected siblings

Raised antibody dependent cell mediated cytotoxicity (ADCC) may indicate an altered immunological state especially in the presence of circulating organ specific autoantibodies. Low affinity E-rosette forming cells (E-RFC) are an important subset of the mononuclear blood cell population and are believed to contain the majority of the cytotoxic lymphocytes ( $K$ cells) [1]. In a previous report we showed that low affinity E-RFC were raised in $57 \%$ of insulin dependent (Type 1) diabetics at the time of diagnosis. In addition, five out of ten genetically susceptible islet cell antibody (ICA) positive unaffected siblings of diabetic children also had raised low affinity ERFC in contrast to one out of fourteen HLA-identical ICA negative siblings [2].

Mononuclear cell infiltration of the islets ("insulitis") has been reported in a proportion of diabetic children who died soon after diagnosis $[3,4$, 5]. There is evidence from studies in vitro of a cytotoxic effect against insulinoma cells using lymphocytes from insulin dependent diabetic children [6].

More recently it has been reported that diabetic patients have raised complement dependent antibody mediated cytotoxicity using intact trypan blue labelled rat islet target cells [7]. In the light of these observations, we decided to investigate $A D C C$ in patients with Type 1 diabetes as near to diagnosis as possible, and also in a group of HLA genetically susceptible siblings who were positive for the presence of ICA.

\section{Subjects and Methods}

Sixteen newly diagnosed insulin dependent diabetics (mean age 17 years, age range 2-36) and 11 ICA positive non diabetic siblings (mean age 16 years, range 4-27) of insulin dependent diabetic probands were studied. The diabetic patients were investigated less than 3 days after diagnosis. A group of 15 healthy controls (mean age 28 years, range 10-42) was also investigated for comparison. All subjects were HLA, A, B and C genotyped [8] and the siblings had at least one HLA-haplotype in common with the proband.

Antibody dependent cell mediated cytotoxicity was evaluated using, as target, ${ }^{51} \mathrm{Cr}$ labelled blood group $0 \mathrm{Rh}$ positive (RI R2) human red blood cells (RBC) sensitised with heat inactivated IgG antiserum (minimum titre 1:64) against erythrocyte antigens $\mathrm{C}$ and D (anti-CD) (Immuno Diagnostica GmbH). Labelling was 
Table 1. Mononuclear antibody dependent cell mediated cytotoxicity \pm SD and low affinity E-RFC \pm SD in controls, newly diagnosed Type 1 diabetics and ICA positive unaffected siblings

\begin{tabular}{llll}
\hline Group & (n) & $\begin{array}{l}\text { \% Mononuclear } \\
\text { ADCC }\end{array}$ & $\begin{array}{l}\text { \% Low affinity } \\
\text { E-RFC }\end{array}$ \\
\hline $\begin{array}{l}\text { Controls } \\
\begin{array}{l}\text { Newly diagnosed } \\
\text { diabetics }\end{array}\end{array}$ & $(15)$ & $39.2 \pm 8.1$ & $14.9 \pm 4.0$ \\
$\mathrm{ICA}^{+}$siblings & $(16)$ & $48.7 \pm 16.0$ & $22.8 \pm 8.9^{\mathrm{c}}$ \\
\hline
\end{tabular}

${ }^{b} \mathbf{P}<0.02$

c $\mathrm{P}<0.01$ By comparison with controls

$\left.{ }^{\mathrm{d}} \mathrm{P}<0.001\right]$

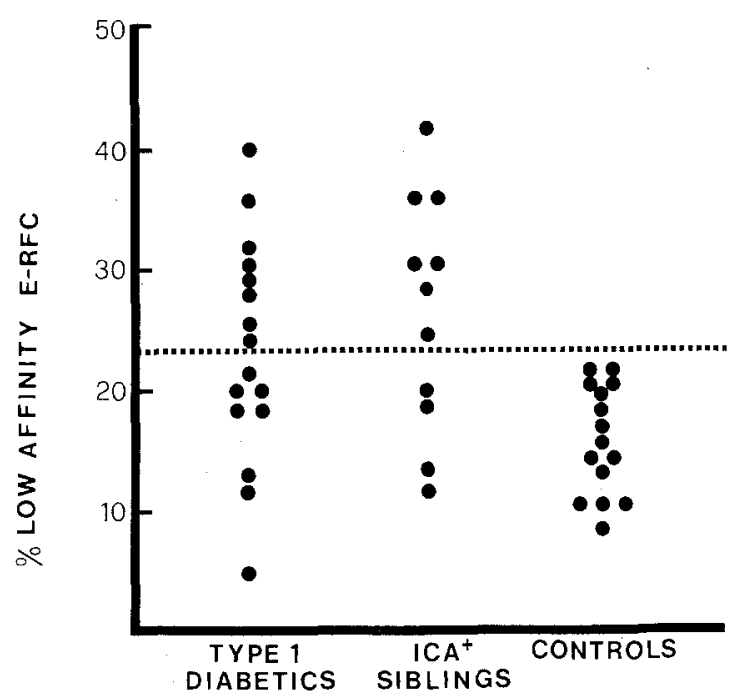

Fig. 1. Distribution of low affinity E-RFC in newly diagnosed insulin dependent (Type 1) diabetics, ICA positive unaffected siblings and normal controls. The dotted line indicates $2 \mathrm{SD}$ above the normal mean

performed by incubating $0.03 \mathrm{ml}$ packed $\mathrm{RBC}$ in $100 \mu \mathrm{Ci}{ }^{51} \mathrm{Cr}$ (Radiochemical Centre, Amersham) for $60 \mathrm{~min}$ at $37^{\circ} \mathrm{C}$. The cells were washed twice and half were coated with antibody by incubation in the anti-CD antiserum at a ratio of $10: 1$ of antiserum to packed $\mathrm{RBC}$ for $45 \mathrm{~min}$ at $37^{\circ} \mathrm{C}$.

The effector cells were mononuclear cells obtained by Ficoll Hypaque gradient centrifugation of venous blood. A monocyte depleted fraction was also prepared by incubating mononuclear cell suspensions in plastic Petri dishes for $90 \mathrm{~min}$ at $37^{\circ} \mathrm{C}$ in a $5 \%$ $\mathrm{CO}_{2}$ humidified atmosphere. The non-adherent cells were gently removed, washed and used as the monocyte depleted fraction. This fraction yielded $99 \%$ pure lymphocytes.

Antibody dependent cell mediated cytotoxicity was assayed in microplates as follows. Antibody coated and non antibody coated labelled RBC $\left(1.0 \times 10^{5}\right.$ in $0.1 \mathrm{ml}$ buffered TC 199 medium supplemented with antibiotics and $10 \%$ foetal calf serum (complete medium)) were mixed with the effector cells $\left(5.0 \times 10^{5}\right.$ in $0.1 \mathrm{ml}$ complete medium) and incubated in $5 \% \mathrm{CO}_{2}$ humidified atmosphere for $20 \mathrm{~h}$. All assays were performed in triplicate. Following the incubation period, the supernatant was collected by means of the Titertek collection system (Flow Laboratories Ltd.) and the radioactivity measured. Antibody dependent cell mediatedcytotoxicity of the mononuclear and monocyte depleted cell fraction was expressed as percentage ${ }^{51} \mathrm{Cr}$ release, calculated according to the following formula:

percentage ${ }^{51} \mathrm{Cr}$ release $=\frac{\mathrm{A}-\mathrm{B}}{\mathrm{C}-\mathrm{D}} \times 100$

where $\mathrm{A}=$ counts/min in the supernatant containing effector cells plus antibody coated targets, $B=$ counts $/ \mathrm{min}$ in the supernatant containing effector cells plus non antibody coated targets, $\mathrm{C}=$ total counts $/ \mathrm{min}$, and $\mathrm{D}=$ counts $/ \mathrm{min}$ in the supernatant containing only antibody coated targets. The intra and inter-assay variability was $5 \%$ and $22 \%$ respectively.

The low affinity E-RFC were measured by a minor modification [2] of the technique of West et al. [1]. ICA were detected on sections of human pancreas by indirect immunofluorescence with undiluted sera [9].

Low affinity E-RFC levels were defined as raised if values greater than 2SD above the normal mean were obtained. After verification of a normal distribution, the mean values in groups were compared by Student's two tailed $t$ test. Correlation coefficient between percentage low affinity E-RFC and percentage ADCC was calculated according to Pearson's test.

\section{Results}

The mean low affinity E-RFC levels were significantly increased in both the newly diagnosed patients and ICA positive siblings (Table 1). Raised low affinity E-RFC levels were found in 8 of $16(50 \%)$ newly diagnosed diabetics and in 7 of $11(64 \%)$ non diabetic ICA positive children (Fig. 1).

The mean percentage ADCC of mononuclear cells is also shown in Table 1. Overall, there was no difference in ADCC between controls and newly diagnosed diabetics, whereas ADCC was significantly increased in ICA positive siblings $(p<0.02)$. When low affinity E-RFC levels were raised, a significant enhancement in the ADCC of mononuclear cells both in newly diagnosed diabetics and ICA positive siblings was found (Table 2). Furthermore, there appeared to be a good correlation between this ADCC and raised low affinity E-RFC $(p<0.01)$ (Fig. 2). In contrast, when low affinity E-RFC levels were normal, ADCC of mononuclear cells in both newly diagnosed diabetics and ICA positive siblings was not different from that measured in controls (Table 2) and no correlation was found with low affinity E-RFC.

The results of ADCC of the monocyte depleted cell fraction are shown in Table 3 . Even though the removal of monocytes reduced ADCC activity in all groups in comparison with mononuclear ADCC, both newly diagnosed diabetics and ICA positive siblings still showed a significant increase in killer activity compared with normal controls. 
Table 2. Mononuclear antibody dependent cell mediated cytotoxicity \pm SD and low affinity E-RFC \pm SD in newly diagnosed Type 1 diabetics and ICA positive unaffected siblings after subdivision into subjects with normal or raised low affinity E-RFC levels

\begin{tabular}{|c|c|c|c|}
\hline Group & (n) & $\begin{array}{l}\% \text { Mononuclear } \\
\text { ADCC }\end{array}$ & $\begin{array}{l}\% \text { Low affinity } \\
\text { E-RFC }\end{array}$ \\
\hline Controls & (15) & $39.2 \pm 8.1$ & $14.9 \pm 4.0$ \\
\hline \multicolumn{4}{|c|}{ Newly diagnosed diabetics with: } \\
\hline $\begin{array}{l}\text { Normal low } \\
\text { affinity E-RFC }\end{array}$ & $(8)$ & $44.5 \pm 12.7$ & $15.7 \pm 5.6$ \\
\hline $\begin{array}{l}\text { Raised low } \\
\text { affinity E-RFC }\end{array}$ & $(8)$ & $52.9 \pm 18.5^{\mathrm{a}}$ & $29.8 \pm 5.1$ \\
\hline \multicolumn{4}{|l|}{$\mathrm{ICA}^{+}$siblings with: } \\
\hline $\begin{array}{l}\text { Normal low } \\
\text { affinity E-RFC }\end{array}$ & (4) & $44.2 \pm 10.4$ & $15.7 \pm 4.3$ \\
\hline $\begin{array}{l}\text { Raised low } \\
\text { affinity E-RFC }\end{array}$ & (7) & $50.7 \pm 6.9^{c}$ & $31.7 \pm 5.7$ \\
\hline
\end{tabular}

\section{Discussion}

In a previous report, we showed that $57 \%$ newly diagnosed Type 1 diabetics and 50\% ICA positive unaffected siblings had an increased proportion of low affinity E-RFC [2]. Since West et al. have shown that the low affinity E-RFC subset includes the majority of $\mathrm{K}$ cells [1], these results provided suggestive evidence for raised $\mathrm{K}$ cell levels in some patients with Type 1 diabetes.

In the present study we have demonstrated that an increase in low affinity E-RFC is accompanied by a parallel enhancement of ADCC in both newly diagnosed diabetics and in unaffected ICA positive siblings. Although the ADCC technique used measured only non specific cytotoxic activity in that the target is not a $B$ cell, the results suggest that an increased killing activity might be present at the time of presentation and even before the onset of clinical symptoms. It is of particular interest that both mononuclear and monocyte depleted ADCC are enhanced in some unaffected ICA positive siblings. Low affinity E-RFC and ADCC in this group were found to be higher than in the overt diabetics. A possible explanation for these findings could be the presence of circulating immune complexes in newly diagnosed patients [11]. Immune complexes could bind to certain effector cells (e.g. K cells), and thus reduce the overall level of antibody dependent cytotoxicity. An alternative explanation for the observation that not all newly diagnosed diabetics show an increase in low

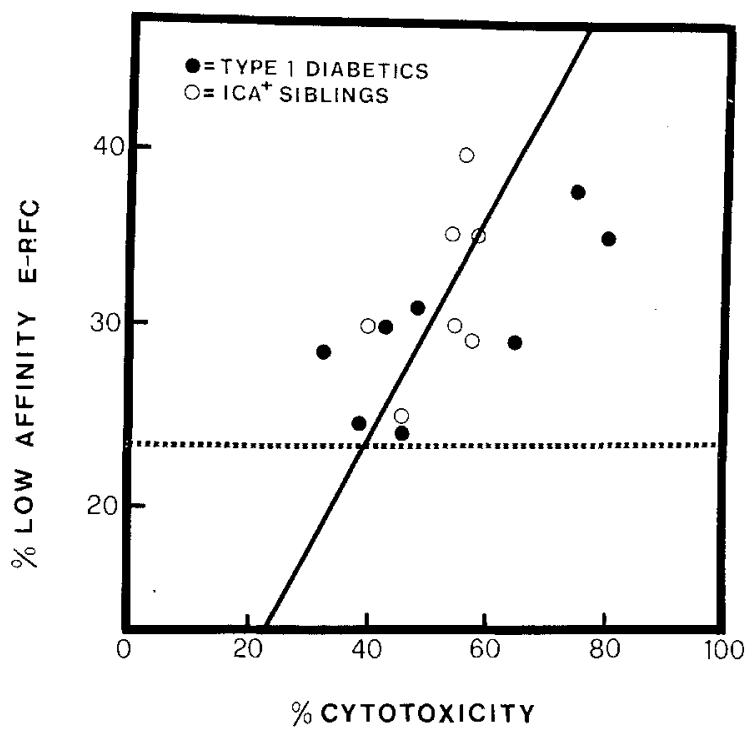

Fig. 2. The relationship between mononuclear antibody dependent cell mediated cytotoxicity and low affinity E-RFC in newly diagnosed insulin dependent (Type 1) diabetics and ICA positive unaffected siblings with raised low affinity E-RFC. $\mathrm{r}=0.63 ; \mathrm{n}=15$; $\mathrm{p}<0.01$

Table 3. Antibody dependent cell mediated cytotoxicity \pm SD of the monocyte depleted cell fraction in: controls, newly diagnosed Type 1 diabetics and ICA positive siblings

\begin{tabular}{lll}
\hline Group & (n) & $\%$ Monocyte depleted ADCC \\
\hline Control & $(10)$ & $14.6 \pm 9.1$ \\
Newly diagnosed & $(8)$ & $23.8 \pm 8.7^{\mathrm{a}}$ \\
diabetics & $(8)$ & $27.9 \pm 16.6^{\mathrm{a}}$ \\
\hline $\mathrm{ICA}^{+}$siblings & (8) \\
\hline
\end{tabular}

${ }^{a} p<0.05 \quad$ compared with controls

affinity E-RFC and ADCC might be pathogenetic heterogeneity in the aetiology of insulin dependent (Type 1) diabetes [10].

It is likely that more than one cell type may be involved as the effector in ADCC and that effectors may change in activity [12]. The anti- $C D$ antiserum has been shown to be more specific in the induction of target lysis by monocytes rather than lymphocytes [13] and this could account for the lack of correlation between mononuclear ADCC and normal low affinity E-RFC levels. In this case therefore, the major proportion of target cell killing would be mediated by monocytes rather than lymphocytes. On the other hand the presence of a correlation between raised low affinity E-RFC and ADCC suggests that the increase in cytotoxic activity may be attributable mainly to killer cells forming this particular type of rosette. Supportive evidence for this is provided by 
the results obtained using monocyte depleted preparations in the same ADCC system. Although monocyte depletion reduced the percentage cytotoxicity by approximately $50 \%$ in all subjects, confirming the importance of monocytes in this type of ADCC, newly diagnosed diabetics and ICA positive siblings showed significantly increased cytotoxicity relative to controls.

A previous report on ADCC in Type 1 diabetes using both HeLa cells and chicken red blood cells as target, showed a decrease of cytotoxic activity [14]. However, in that study the diabetics were not studied at the time of diagnosis but several months later, and the level of circulating $\mathrm{K}$ cells was not estimated. The duration of the disease is important, since we know that in Type 1 diabetes the $\mathrm{K}$ cell levels measured with the low affinity E-RFC technique tend to return to normal levels within 12 months from diagnosis [2]. Moreover in autoimmune thyroid disease [15] and in autoimmune polyendocrine disease [16] ADCC is increased only within the first year of disease. Thus in diabetes, enhanced ADCC may only be detected near the time before and immediately after diagnosis. The observation that the occurrence of complement fixing ICA could be related to the onset of the disease [17] and the present data of raised ADCC at diagnosis indicate the possible importance of both humoral and cell mediated reactions in the ultimate destruction of $B$ cells.

In conclusion our data indicate that an increase in the low affinity E-RFC subset reflects raised cytotoxic activity. We suggest that it will be important to investigate whether such increased cytotoxic activity can be demonstrated against human pancreatic B cells as the specific target tissue.

Acknowledgements. This work was supported by grants from the Joint Research Board, St. Bartholomew's Hospital, the Medical Research Council, the Wellcome Foundation, and the C. N. R. Italy. We are grateful to Dr. Peter Lydyard for his valuable comments and to Dr. J. Lister and other physicians for allowing the study of their patients. We are also indebted to Miss B. Watson and Miss V. Drummond who performed the HLA typing.

\section{References}

1. West WH, Boozer RB, Herberman RB (1978) Low affinity Erosette formation by the human K cell. J Immunol 120: 90-95

2. Pozzilli P, Sensi M, Gorsuch A, Bottazzo GF, Cudworth AG (1979) Evidence for raised K cell levels in Type 1 diabetes. Lancet II: $173-175$
3. Gepts W (1965) Pathologic anatomy of the pancreas in juvenile diabetes mellitus. Diabetes 14: 613-639

4. Junker K, Egeberg, J, Kromann H (1977) An autopsy study of the islets of Langerhans in acute-onset juvenile diabetes mellitus. Acta Pathol Microbiol Scand [A] 85: 699-706

5. Yoon JW, Austin M, Onodera T, Notkins AL (1979) Virus induced diabetes mellitus in man. $N$ Engl $J$ Med 300: 1173-1179

6. Huang SW, MacLaren NK (1976) Insulin-dependent diabetes: a disease of autoaggression. Science 192: 64-66

7. Rittenhouse HG, Oxender DL, Pek S, Ar D (1980) Complement mediated cytotoxic effects in pancreatic islets with sera from diabetic patients. Diabetes 29: 317-322

8. Joysey VC, Wolf E (1978) HLA-A, B and C antigens, their serology and cross reaction. Br Med Bull 34: 217-222

9. Bottazzo GF, Cudworth AG, Moul DJ, Doniach D, Festenstein $H$ (1978) Evidence for a primary autoimmune type of diabetes mellitus. Br Med J II: 1253-1255

10. Cudworth AG (1980) Current concepts of aetiology: Type 1 (insulin dependent) diabetes. In: Bellingham AJ (ed) Advanced medicine 16. Pitman Medical, Tunbridge Wells, $p$ 123-135

11. Irvine WJ, Al-Khateeb SF, Di Mario U, Feek CM, Gray RS, Edmond B, Duncan LJ (1977) Soluble immunecomplexes in the sera of newly diagnosed insulin dependent diabetics and in treated diabetics. Clin Exp Immunol 30: 16-21

12. LiShem P, Lydyard P, Penfold P, Roitt IM (1979) Evidence for antibody-dependent cell-mediated cytotoxicity by $\mathrm{T}$ cells bearing receptors for IgG. Clin Exp Immunol 35: 276-285

13. Shaw GM, Levy PC, LoBuglio AF (1978) Human lymphocyte antibody-dependent cell-mediated cytotoxicity (ADCC) towards human red blood cells. Blood 52: 696-705

14. Schernthaner G, Ludwig H, Kraft D, Mayr WR (1979) Antibodydependent killer-cell activity in HLA-DR typed insulin dependent diabetics. In: Symposium on Autoimmune Aspects of Endocrine Disorders. Pisa, Serono Symposia International Press, p 43 (Abstract)

15. Calder EA, Irvine WJ, Davidson ND, Wu F (1976) T, B and K cells in autoimmune thyroid disease. Clin Exp Immunol 25: 17-22

16. Pozzilli P, Andreani D, Sensi M, Wolf E, Taylor M, Bottazzo GF, Cudworth AG (1980) K cells and antibody dependent cytotoxicity in autoimmune polyendocrine disease. In: Sixth International Congress of Endocrinology, Melbourne, p 529 (Abstract)

17. Bottazzo GF, Dean BM, Gorsuch AN, Cudworth AG, Doniach D (1980) Complement fixing islet cell antibodies (CF-ICA) in Type 1 diabetes: possible monitor of active beta cèll damage. Lancet I: 668-672

Received: April 28, 1980,

and in revised form: October 8,1980

\author{
A. G. Cudworth \\ Medical Unit \\ St. Bartholomew's Hospital \\ West Smithfield \\ London, EClA 7BE \\ England
}

